\title{
$C_{0} \mathbf{I} \cdot \mathbf{R}^{\circ} \mathbf{P} \cdot \mathrm{E} \cdot \mathrm{E}$
}

Centre Interuniversitaire sur le Risque, les Politiques Économiques et l'Emploi

Cahier de recherche/Working Paper 11-20

\section{Book Review of The Theory of Corporate Finance}

Georges Dionne

Juillet/July 2011

Dionne: Canada Research Chair in Risk Management and Finance Department, HEC Montreal, Canada; and CIRPÉE

georges.dionne@hec.ca 


\begin{abstract}
:
The book proposes an original contribution to the economics and finance literature by developing the foundations of corporate finance. It also covers in detail various corporate governance issues faced by organizations. The common treatment of corporate finance and corporate governance started with the contribution of Williamson (Journal of Finance, 1988), who argued that corporate finance and corporate governance must be treated simultaneously because they are complementary. This book fills this gap in the literature.
\end{abstract}

Keywords: Corporate finance, corporate governance, ownership and control, managerial incentive, outsider incentive, stakeholder society

JEL Classification: D80, G14, G33, G34 


\section{Book review of The Theory of Corporate Finance}

Jean Tirole has contributed to many aspects of economic theory, including industrial organization, public economics, contract theory, game theory, finance, and corporate governance. This book proposes an original contribution to the economics and finance literature by developing the foundations of corporate finance. It also covers in detail various corporate governance issues faced by organizations, including financial institutions such as banks and insurance companies. Although the emphasis is on theory, the book contains many examples and stylized facts that illustrate concepts of corporate finance theory, such as security design, incentives, and controls, which are the basis of modern corporate finance.

The book consists of sixteen chapters divided into six parts, a seventh part containing answers to selected exercises and review problems, a comprehensive list of references at the end of each chapter, and a subject index. Its content is devoted to positive and normative analyses of corporate finance and is directed at an audience interested in the theoretical foundations of corporate finance. The book is designed for professors and graduate students, but can also be of interest to practitioners with a strong background in economics and finance. To my knowledge, no such text has been published before, and the book fills an important gap in the literature. It contains formal economic analyses (with equations and models) presented with exceptional intuition. The subjects covered are important for the understanding of almost all facets of corporate finance. At the end of the introduction, the author discusses omissions such as a detailed empirical analysis of the main theories developed in the book, taxes, bubbles, behavioral finance, and international finance. The book is an important input for the readers of The Journal of Risk and Insurance and remarkably supplements the empirical contributions on corporate 
governance in the insurance industry presented in this special issue of the Journal (September 2011).

The first two chapters introduce the reader to corporate finance by reviewing the main institutional features, empirical regularities, and policy issues discussed in the literature related to corporate governance and corporate financing. The goal of this section is to present an overview of corporate institutions in order to motivate the theoretical analyses presented in the next parts. It covers many subjects related to corporate governance, such as the separation between ownership and control, managerial incentives, and stakeholder society. It also presents stylized facts on corporate financing related to debt instruments, equity instruments, and financing patterns.

The second part of the book starts the theoretical development of the microeconomics of corporate finance, which the author separates into several branches. The first branch, presented in this part, addresses the incentive problems of insiders. The chapters consider financial contracting with alternative assumptions regarding information asymmetries between insiders and outsiders. For example, Chapter 3 proposes a fixed-investment model with moral hazard and credit rationing, while Chapter 4 analyzes determinants of borrowing capacity. Chapter 5 extends the discussion to multiperiod financing where liquidity management can become a complement to the standard solvency leverage requirement imposed by lenders. Chapter 6 introduces adverse selection at the financing stage, which increases the difficulty for insiders to raise project financing. Finally, Chapter 7 shows how product or market characteristics can affect financing choices.

The next two parts treat situations where both insiders and outsiders are active, which may induce additional incentive problems. This is because outsiders can affect the distribution of events chosen by the insiders. For instance, the board of directors may ask the CEO to change his investment strategy or to forgo an acquisition. The introduction of outsiders' 
incentives improves the significance of the models, but increases the difficulty of financial contracting. The Modigliani-Miller Theorem (complete markets, no transaction costs, no taxes, no bankruptcy costs) is also questioned, because this context provides security holders with their own incentives for affecting firm management.

Part III of the book is devoted to the monitoring of management by security holders. Chapter 8 is concerned with the social benefits and cost of passive monitoring, using the firms' stock market price to measure the value of assets in place. In contrast, Chapter 9 introduces active monitoring by outsiders. This monitoring can alleviate adverse selection or reduce the cost of moral hazard. However, there is no free lunch: optimality is a function of various costs such as the availability of monitoring capital and variation in future competition. Part IV continues to develop the monitoring of management by security holders by introducing a control-rights approach to corporate finance. Chapter 10 presents circumstances where control rights should be allocated to security holders whose incentives are not aligned with managerial interests when firm performance is poor. Chapter 11 analyzes the case wherein raiders take over the firm. The author develops a normative theory of takeovers and studies their social efficiency.

Chapter 12 in Part V takes into account the existence of security holders' differences in preferences for state-contingent returns (short horizon associated with safe securities and longer horizon associated with riskier securities). Part VI analyzes the link between corporate finance and macroeconomic activity and policy. Chapter 13 introduces corporate finance in a general equilibrium environment permitting, for example, endogenous determination of factor prices. Chapter 14 endogenizes the resale value of assets in capital allocation. Chapter 15 discusses the existence of store of value in the economy and its consequences on demand for liquid assets. The private sector may create its own inside liquidity, but this may not be sufficient for the functioning of the economy, which may justify government intervention. Such intervention creates outside liquidity 
backed by future taxation, for example. Further, the whole economy is characterized by laws and regulations that affect corporate profitability. Chapter 16 defines the public institutions that influence the behavior of borrowers, investors, and other stakeholders.

The common treatment of corporate finance and corporate governance started with the contribution of Williamson (Journal of Finance, 1988), who argued that corporate finance and corporate governance must be treated simultaneously because they are complementary. Jean Tirole's book offers the first unified treatment of this complementarity. Corporate governance problems are used to justify a comprehensive treatment of corporate finance, starting from a simple principal agent problem inside the firm to a complex general equilibrium model with insiders, outsiders, and regulators. The basic premise is that inside managers may not act in the interest of the firm's fund providers, but that outsiders may also have their own incentives that may affect the final results. Incentive mechanisms must then be put in place to ally the interests of all stakeholders.

Many recent empirical studies in finance, insurance, and risk management show that a firm's performance is affected by corporate governance issues, but very few theoretical contributions offer models that integrate the endogenous forms of corporate structure or governance and corporate financing. In other words, corporate governance forms are still treated as exogenous in the study of endogenous corporate financing, from simple debt contracts to the whole capital structure. The recent financial crisis clearly showed that corporate governance is significant in the functioning of the financial sector, including banking and insurance firms. We hope that this book will help motivate future research by integrating the two fields.

\section{References}


Tirole, Jean (2006), The Theory of Corporate Finance, Princeton University Press, 644 pages.

Williamson, Oliver E. (1988), Corporate Finance and Corporate Governance, Journal of Finance XLIII, 567-591. 